\title{
Development of Student's Worksheet to Analyze Student's Algebraic Thinking Based on SOLO Taxonomy
}

\author{
Anis Farida Jamil \\ Study Program of Mathematics Education \\ University of Muhammadiyah Malang, Indonesia \\ anisfarida@umm.ac.id
}

\begin{abstract}
The aim of this research and development (R\&D) is to develop student's worksheet to analyze student's algebraic thinking based on SOLO taxonomy with quality criteria: valid and practical. This R\&D adapted from ADDIE model consisting five stages that are Analysis, Design, Development, Implementation, and Evaluation. The subject of this R\&D is students of Study Program of Mathematics Education's academic year 2017. Instruments that used in this R\&D are validation sheet, observation of student's activities sheet, and questionnaire. Based on the result of validation, this student's worksheet had valid criteria. This student's worksheet had practical criteria that showed by the result of activities students observation had good criteria and students had given positive responses for instructional using student's worksheet.
\end{abstract}

Keywords-Development, Student's Worksheet, Student's Algebraic Thinking, SOLO Model

\section{INTRODUCTION}

Algebra is a subject in mathematics whose characteristics are the use of symbol. The development of symbols in Algebra is an important point used in almost every aspect of mathematics [1], [2], [3]. Algebraic thinking ability is a generalized form of arithmetic thinking [2]. Algebraic thinking ability is concerned with the importance of representation, structure of numbers, patterns and functions, reasoning, and mathematical modeling [4], [5], [6]. There are a lot of problems in everyday life whose solutions require algebraic thinking ability; hence algebraic thinking ability is very important [7].

One of the cognitive theories that characterize algebraic thinking ability is the SOLO (Structure of Observed Learning Outcome) cognitive theory [8]. The SOLO taxonomy classifies algebraic thinking ability into four levels: (1) unistructural, (2) multistructural, (3) relational, and (4) extended abstract. SOLO Taxonomy is a model of cognitive psychology that more emphasis on investigation and internal processes of students in solving problems than students' correct answers [8]. Algebraic thinking ability processes can be observed when students solve algebraic problems [9]. Analyzing student algebraic thinking ability based on SOLO taxonomy is needed to know at what level of algebraic thinking the students are. So, by knowing the level of student's algebraic thinking ability, it is going to be useful to provide appropriate action in improving student algebraic thinking.

The use of student's worksheets (LKM) in learning is as the media for analyzing algebraic thinking ability based on SOLO taxonomy. For instance, the activities undertaken in this research are mainly focused to develop the LKM. The LKM contains Superitem Test issues. The Superitem Test contains four open-ended problems, each of which represents student's algebraic thinking ability based on SOLO taxonomy [8].

Many previous studies have examined algebraic thinking ability. The research titled Developing Algebraic Thinking Ability in a Community of Inquiry shows algebraic thinking ability development towards the subject of the study [10]. Another study entitled A Research into the Year Five Pupils' Pre-Algebraic Thinking Ability in Solving PreAlgebra Problem shows satisfying results in solving problems by involving variables, grouping strategies, and the most commonly used arithmetic strategies [11]. Based on the explanations given, then the purpose of this study is to develop LKMs to analyze student's algebraic thinking ability based on SOLO taxonomy.

\section{METHODOLOGY}

This research and development adopted the ADDIE model. This model included the steps of Analysis Phase, Design Phase, Development Phase, Implementation Phase, and Evaluation Phase [12]. In the analysis phase, the activities undertaken were analyzing student characteristics and analyzing the learning objectives. At the design stage, the activities undertaken were designing lessons through Lesson Plan and creating an LKM's format. In addition, the creation of validation sheets, student activity observation sheets, and student response questionnaires were undertaken at this stage. The activity that was nailed in Development Phase was to develop an LKM containing a Superitem Test. The Superitem Test contained four open-ended issues in which each of them represented student's algebraic thinking ability based on SOLO taxonomy. [8] The next stage was Implementation Phase by testing the validity of the LKM to 
the expert validators and implementing the learning that the LKM had developed. During the learning activities, there were observers who would observe student activities. In addition, giving a questionnaire was also done at this stage. The last stage was evaluation. Evaluation Phase activities which is aimed to see the achievement of the LKM's goal to analyze students' algebraic thinking ability based on SOLO taxonomy. In addition, in the last stage, the results of student activity observation and student questionnaire results were also obtained.

\section{RESULT AND DISCUSSION}

\section{A. Analysis Phase}

The results of the analysis of student characteristics that seen from the test results conducted before the research showed that students have heterogeneous ability. There are $23 \%$ of low-skilled students whose scores are below 45 . Medium-scaled students whose scores are in the range of 45 to 75 are $51 \%$. The other $26 \%$ are the high-ability students whose scores are above 75 with a maximum score of 100 .

The learning material used in this research is a twovariable linear equation system. There are two learning objectives that are expected to be achieved. Those are: 1) the student can determine the mathematical model of the given problem which is the linear equation of two variables; 2) the student can solve the problem related to the linear equation of two variables.

\section{B. Design Phase}

At the Design Phase, the LKM's format will be developed. The LKM's designed formats are tables for filling student identities, learning materials, learning objectives, guidance on LKM work, and four issues that each of them follow the space to fill in the answers.

Lesson Plan is used in this research and development to facilitate the implementation of LKMs on learning. Lesson Plan contains the component of the name of the course, the name of the lecturer, the study program, the semester, the time allocation, the learning achievement, the final ability, the indicator, the subject, and the references. In addition to the Lesson Plan, there is also a table containing the stages of learning. Stages of learning include learning activities, methods, media, and time allocation of each stage.

The validation sheet is designed to be used by expert validators in determining the validity of the LKM. The validation sheet contains a scoring guide, an assessment table containing descriptors and scores, and a comment section. While the student activity observation sheet and student response sheet each contain the instructions for filling the score, descriptor evaluation table, and comment section.

\section{Development Phase}

At this stage, the lesson plan is developed in accordance with the pre-designed format design. LKMs contain four issues called Superitem Tests that can represent students' algebraic thinking ability based on SOLO taxonomy. Four algebraic thinking abilities based on SOLO's taxonomy are Unistructural, Multistructural, Relational, and Extended Abstract. The first problem represents Unistructural algebraic thinking. Problems created with student characteristics focus on a single revelation of information on a given problem to respond to the problem. The second problem represents Multistructural algebraic thinking. The second problem has the characteristics of students focusing on some relevant information to respond to the problem but this information is still not being integrated. The third problem represents relational algebraic thinking. This third issue has the characteristics of students integrating all aspects of information provided to each other into a coherent structure. Finally, the fourth problem represents Extended Abstract algebraic thinking. This last problem has the characteristics in which students need to generalize the structure into a more abstract situation. The explanation can be seen in Table 1 below.

TABLE 1. DESCRIPTION OF PROBLEMS THAT MENTIONED IN STUDENT'S WORKSHEET

\begin{tabular}{lll}
\hline Problems & $\begin{array}{l}\text { Algebraic } \\
\text { thinking } \\
\text { ability Based } \\
\text { on SOLO } \\
\text { Taxonomy }\end{array}$ & Characteristic of the Designed Problem \\
\hline First & Unistructural & $\begin{array}{l}\text { Students focus on single relevant } \\
\text { information on the given problem to } \\
\text { provide responds toward the problem. }\end{array}$ \\
\hline Second & Multistructural & $\begin{array}{l}\text { Students focus on several relevant } \\
\text { information to give responds toward the } \\
\text { problem, but the information is still treated } \\
\text { without being integrated. }\end{array}$ \\
\hline Third & Relational & $\begin{array}{l}\text { Students integrate all of the aspects from } \\
\text { the given information to each other into a } \\
\text { coherent structure. }\end{array}$ \\
\hline Fourth & $\begin{array}{l}\text { Extended } \\
\text { Abstract }\end{array}$ & $\begin{array}{l}\text { Students generalize a structure into an } \\
\text { abstract situation. }\end{array}$ \\
\hline
\end{tabular}

Superitem Test is constructed by adapting Lian \& Wun model [13]. Here are the problems (superitem test) proposed in the LKM. 
Lukisan yang berbentuk belah ketupat digantungkan di dinding secara berjajar. Lukisan tersebut dipaku pada keempat sudut lukisan tetapi bagian dua lukisan yang saling berdekatan hanya dilekatkan dengan 1 paku seperti gambar dibawah ini.

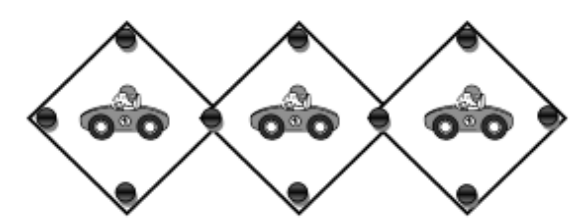

Level 1: Unistructural

Berapa banyak paku yang dibutuhkan untuk menggantungkan 4 lukisan dengan cara tersebut?

\section{Level 2: Multistructural}

Berapa banyak paku yang dibutuhkan untuk menggantungkan 10 lukisan?

Berapa banyak paku yang dibutuhkan untuk menggantungkan 16 lukisan?

Berapa banyak paku yang dibutuhkan untuk menggantungkan 22 lukisan?

Tampilkan jawabanmu di dalam tabel.

\section{Level 3: Relational}

Jika kamu memiliki sebanyak y lukisan, berapa banyak paku yang dibutuhkan?

Tuliskan persamaan linier untuk menentukan banyaknya paku untuk sebarang banyaknya lukisan. Misalkan $t$ menunjukkan banyaknya paku dan $p$ menunjukkan banyaknya lukisan. Berapa banyak lukisan yang dapat digantung jika banyaknya paku adalah 97 ? Gunakan persamaan liniermu untuk menyelesaikannya.

\section{Level 4: Extended Abstract}

"Aku tidak punya cukup paku untuk menggantungkan banyak lukisan dengan cara seperti itu!", kata Lisa. Cobalah untuk menciptakan persamaan linier baru yang merepresentasikan banyaknya paku (t) untuk sebarang banyaknya lukisan (p) untuk membantu Lisa.

\section{Implementation Phase}

Implementation Phase begins with performing LKM validation by two expert validators. After being declared valid, learning is implemented using the LKM. In the learning activities, there are two observers who are tasked to observe the learning activities and provide an assessment on student activity observation sheets in accordance with what has been observed. The last activity when learning by using LKM has been done then the questionnaire spread to the students. The questionnaire was distributed to see the responses given by students to the learning by using the LKM.

\section{E. Evaluation Phase}

Based on the students' work in solving the problems in LKM, there is no result that no students have the Uni-structural algebraic thinking ability stage. There are $51 \%$ of students on Multi-structural algebra thinking. There are $37 \%$ of students on Relational algebraic thinking. While the rest, there are $12 \%$ of students with Extended Abstract algebraic thinking. The data can be seen in Table 2 below.

TABLE 2. PERCENTAGE OF STUDENTS IN ALGEBRAIC THINKING

\begin{tabular}{|c|c|c|}
\hline $\begin{array}{l}\text { Algebraic } \\
\text { thinking } \\
\text { ability Based } \\
\text { on SOLO } \\
\text { Taxonomy }\end{array}$ & $\begin{array}{l}\text { Characteristic of Students in } \\
\text { Solving Problem }\end{array}$ & $\begin{array}{l}\text { Number of } \\
\text { Students } \\
(\%)\end{array}$ \\
\hline Unistructural & $\begin{array}{l}\text { Students focus on single relevant } \\
\text { information on the given problem to } \\
\text { provide responds toward the problem. }\end{array}$ & 0 \\
\hline Multistructural & $\begin{array}{l}\text { Students focus on several relevant } \\
\text { information to give responds toward } \\
\text { the problem, but the information is } \\
\text { still treated without being integrated. }\end{array}$ & 51 \\
\hline Relational & $\begin{array}{l}\text { Students integrate all of the aspects } \\
\text { from the given information to each } \\
\text { other into a coherent structure. }\end{array}$ & 37 \\
\hline \multirow[t]{2}{*}{$\begin{array}{l}\text { Extended } \\
\text { Abstract }\end{array}$} & $\begin{array}{l}\text { Students generalize a structure into an } \\
\text { abstract situation. }\end{array}$ & 12 \\
\hline & Total & 100 \\
\hline
\end{tabular}

The LKM's validation results performed by two expert validators show valid criteria. Based on the results of the validation, LKM can be implemented on learning. The result of observation on student activity in learning using LKM shows good criteria. The results of questionnaires distributed to students after obtaining learning using the LKM get a positive response. Based on the observations of student activities and the results of the questionnaire, it can be said that the LKM has met the practical criteria.

TABLE 3. ADVISABILITY OF STUDENTS' WORKSHEET

\begin{tabular}{|c|c|c|}
\hline Imlementation Result & Category & Conclusion \\
\hline Validation Result & Valid & Valid \\
\hline $\begin{array}{l}\text { Observation of Student's } \\
\text { Activity Result }\end{array}$ & Good & Practical \\
\hline
\end{tabular}




\section{CONCLUSION}

The first phase done in this research is analysis phase, where the result of characteristic analysis showed that students have heterogeneous ability. In the second phase is the Design Phase. At the Design Phase, the LKM format will be developed. The third stage is Development Phase. At this stage, the LKM is developed which contains four problems called super-item tests that can represent students' algebraic thinking ability based on SOLO taxonomy. The fourth stage is implementation. Implementation Phase begins with performing LKM validation by two expert validators. After being declared valid, learning is implemented using the LKM. The last stage is evaluation. At the Evaluation Phase, the LKM shows valid and practical criteria. LKM media can be used to analyze student's algebraic thinking.

\section{REFERENCES}

[1] J. Ainley, "Algebraic Thinking and Mathematics Education", in Proceedings of CERME 6, Lyon France, 2009.

[2] G. Egodawette, D. Stoilescu, "Grade 11 Students' Interconnected Use of Conceptual Knowledge, Procedural Skills, and Strategic Competence in Algebra: a Mixed Method Study of Error Analysis", European Journal of Science and Mathematics Education Vol.3 No 3, 289-305, 2015

[3] D.W. Carraher, A.D. Schliemann, \& B.M. Brizuela, "Bringing out the algebraic character of arithmetic: From children's ideas to classroom practice" [Electronic version]. Mahwah, NJ: Lawrence Erlbaum $\begin{array}{lllll}\text { Associates. } & \text { Retrieved } & 5 & \text { May } & \text { 2009, from }\end{array}$ http://www.earlyalgebra.terc.edu/publications.htm [diakses: 14 Desember 2017]

[4] J. Van de Walle, S. Folk, Elementary and middle school mathematics: Teaching developmentally Second Canadian Edition, Toronto, ON: Pearson Education Canada, 2008.

[5] C. Greenes, C. Findell, Algebra Puzzles and Problems (Grade 7), Mountain View, CA: Creative Publications, 2008.

[6] A. Yunarni, "Profil Pemahaman Notasi Aljabar Ditinjau Dari Kemampuan Verbal Siswa di Kelas V Sekolah Dasar", Jurnal Daya Matematis, Vol. 3 No. 1, 2015

[7] W.D. Warsitasari, "Berpikir Aljabar dalam Pemecahan Masalah Matematika" Jurnal APOTEMA, Vol. 1 No. 1, 2015.

[8] L.H. Lian, \& N. Idris, "Assessing Algebraic Solving Ability of Form Four Students", International Electronic Journal of Mathematics Education, Vol. 1, No. 1, 2006.

[9] R. Laisouw, Profil Respon Siswa Dalam Memecahkan Masalah Aljabar Berdasarkan Taksonomi SOLO Ditinjau Dari Minat Belajar Matematika, Tesis tidak diterbitkan, Ternate: Program Pascasarjana Universitas Muhammadiyah Maluku Utara Ternate, 2012.

[10] C.V. Berg, Developing Algebraic Thinking in a Community of Inquiry, Doctoral Dissertation. Norway:University of Agder Kristiansand, 2009.

[11] G.W. Ling, A Research Into YearFIve Pupils'Pre-Algebraic Thinking in Solving Pre-Algebra Problems, Ph.D Thesis. Penang: University Sains Malaysia, 2008

[12] N. Aldoobie, “ADDIE Model”, American International Journal of Contemporary Research, Vol. 5 No.6, 2015.

[13] L.H. Lian \& Wun, "Superitem Test: An Alternative Assessment Tool To Assess Students' Algebraic Solving Ability”, International Journal for Mathematics Teaching and Learning, 2009. 